\title{
Microbial, Urease Activities and Organic Matter Responses to Nitrogen Rate in Cultivated Soil
}

\author{
Sun Jingjing ${ }^{1}$, Zhu Mijia ${ }^{1}$, Yang Xiaoqia ${ }^{2}$, Zhang $\mathrm{Chi}^{1}$ and Yao Jun ${ }^{*}, 1$
}

\begin{abstract}
${ }^{1}$ School of Civil \& Environmental Engineering and National "International Cooperation Based on Environment and Energy" and Key Laboratory of "Metal and Mine Efficiently Exploiting and Safety" Ministry of Education, University of Science and Technology Beijing, Beijing 100083, P.R. China
\end{abstract}

${ }^{2}$ College of Resources and Environment Science, Agricultural University of Hebei, Baoding, Hebei, 071001, P.R. China

\begin{abstract}
Nitrogen $(\mathrm{N})$ fertilizer is an important field management, this paper was to investigate the responses of microbial activity measured by microcalorimetric technique, urease activity and organic matter to proper nitrogen $(\mathrm{N})$ fertilizer in cultivated system in the North China Plain. The microcalorimetry results showed that microorganisms under proper $\mathrm{N}$ fertilizer rate got the efficient metabolism. The maximum heat production $(P \max )$ of microcalorimetry parameter implied that increasing the $\mathrm{N}$ fertilizer rate, $P \max$ did not increase always but firstly increased than decreased. In addition, from soil urease activity and organic matter studies, high soil urease activity due to both $\mathrm{N}$ fertilizer rate and growth stage and these had light influence on soil organic matter. These results suggest that only proper amount of $\mathrm{N}$ fertilizer rate and suitable topdressing for a good wheat-growing environment.
\end{abstract}

Keywords: Microbial activity, microcalorimetry, organic matter, urease

\section{INTRODUCTION}

Nitrogen $(\mathrm{N})$ fertilizer application is an important measure to improve the soil fertility and crop yield [1], also it is one of the most management measure in agriculture [2]. Excess $\mathrm{N}$ fertilizer into soil is very common in China at present [3]. However, with increasing yield of crops and soil fertility due to $\mathrm{N}$ fertilizer, also making a large amount of $\mathrm{N}$ wasted, leading to $\mathrm{N}$ leach polluting ground water, ammonia volatilization and eutrophication caused pollution to environment [4]. Winter wheat (Triticum aestivum L.) is the major crop in China. The North China Plain is the most important grain-producing areas in China, two-thirds of China's winter wheat come from here [5]. Therefore, to study this area's soil on different growth stages of winter wheat is extremely important, also it is becoming essential to research the microbial activity, urease activity and soil organic matter under different $\mathrm{N}$ rates in winter wheat system. It will provide proper $\mathrm{N}$ availability, reduce the pollution of $\mathrm{N}$ on the environment play a guiding role.

Soil microorganisms are important components of soil ecosystem, leading the nutrient cycle [6] and energy flow, meanwhile, it play an important role on maintaining the ecosystem stability and sustainability. $90 \%$ of microorganism involved in the soil reaction process, could change the soil fertilization. For example, soil bacterial can enhance the availability of nutrients [7]. The proper amount of nitrogen

*Address correspondence to this author at the School of Civil \& Environmental Engineering, University of Science and Technology Beijing, Beijing, 100083, P.R. China; Tel:+86-10-62333305;

E-mail: yaojun@ustb.edu.cn fertilizer can improve the activity of microorganism, then improve soil fertility, also reduce the environment pollution. Nowdays, microbial technologies gain an increasing attention for agricultural and environmental problems [8]. In this paper, we use microcalorimetry technology. It is a simple and straightforward method for the study of microbial activity. It can measure the heat flow of microbial process, obtain a kinetic and thermodynamic parameters.

Soil organic matter (SOM) is a critical factor which affecting soil quality [9], decreasing soil erosion [10], improving water holding capacity [11] and keeping the sustainable development of agriculture ecosystem [12]. A part of N fertilizer may become SOM when it into soil [13]. Meanwhile, SOM is accounted for atmospheric carbon once it preservation in soils [14]. Therefore, $\mathrm{N}$ fertilizer use change, according to change the organic matter accumulation in soil and crop growth [15], thus, impact agricultural ecosystem. On the other hand, soil urease is one of most active hydrolytic enzymes in the soil, the hydrolysis of soil urease to urea which was applied into the soil, release ammonium that can use by crops, play an important role in soil $\mathrm{N}$ cycle. Soil urease is paid more and more attention because it can be used as important indexes to evaluate SOM and $\mathrm{N}$ application [16] and more quickly response to environment change and agricultural management [17].

The main objective of this study was to evaluate and compare soils from long-term $\mathrm{N}$ fertilizer experiments in the North China Plain. The experiments have the same range of phosphorous-potassium fertilizer treatments and field management, different $\mathrm{N}$ fertilizer treatments. We investigated the different $\mathrm{N}$ fertilizer on soil microbial and 
urease activity, soil organic matter. We also examined what the relative effects were of underlying microcalorimetry parameters, urease activity and organic matter.

\section{MATERIAL AND METHODS}

\subsection{Soil Sampling Sites and Sampling Collection}

Soil sampling selected in The North China Plain, The area is a temperate monsoon climate, with annual average temperature $12^{\circ} \mathrm{C}$, annual precipitation $550 \mathrm{~mm}$. Soil samples taken down from 0 to $30 \mathrm{~cm}$ soil depth and were taken on trough winter stage, reviving stage, jointing stage, blossoming stage, maturing stage of winter wheat respectively. Soil samples was air dried and passed through a $1 \mathrm{~mm}$ sieve for determination of microbial, urease activities and a $0.15 \mathrm{~mm}$ sieve for organic matter. It has a sandy loam texture $(0-20 \mathrm{~cm})$ with $37 \%$ sand, $48 \%$ silt and $13 \%$ clay, $\mathrm{pH}$ 8.5 , the surface soil $(0-20 \mathrm{~cm})$ contained $16.8 \mathrm{~g} \mathrm{~kg}^{-1}$ organic matter, $0.9 \mathrm{~g} \mathrm{~kg}^{-1}$ total nitrogen, $16.6 \mathrm{mg} \mathrm{kg}{ }^{-1}$ Olson-P, $99.3 \mathrm{mg} \mathrm{kg}^{-1}$ Olsen-K, CEC $\left(16.3 \mathrm{cmol} \mathrm{kg}^{-1}\right)$.

\subsection{Experimental Design}

Five $\mathrm{N}$ fertilizer treatments were designed: $0 \mathrm{~kg} \mathrm{hm}^{-2}(\mathrm{~N} 0)$, $100 \mathrm{~kg} \mathrm{hm}^{-2}$ (N1), $180 \mathrm{~kg} \mathrm{hm}^{-2}$ (N2), $250 \mathrm{~kg} \mathrm{hm}^{-2}$ (N3), $300 \mathrm{~kg}$ $\mathrm{hm}^{-2}$ (N4). N fertilizer applied as urea, $\mathrm{P}$ and $\mathrm{K}$ fertilizer applied as calcium superphosphate and potassium chloride which the rate was 120 and $120 \mathrm{~kg} \mathrm{hm}^{-2}, \mathrm{ZnSO}_{4}$ fertilizer applied as $15 \mathrm{~kg} \mathrm{hm}^{-2}$. All the $\mathrm{P}, \mathrm{K}$ and $\mathrm{ZnSO}_{4}$ fertilizer were applied into soil as basic fertilizer, and $\mathrm{N}$ fertilizer applied as basic fertilizer (40\%), topdressing at jointing (40\%) and blossoming (20\%) stage. From sowing in October to harvest in next June needed to irrigate 4 times. Other field management measures are the same in each treatment.

\subsection{Microcalorimetry}

TAMIII can provide a metabolic heat output production of the soil system. $4 \mathrm{ml}$ of ampouls with soil $(1 \mathrm{~g})$ and $0.2 \mathrm{ml}$ nutrition solution containing glucose $(2.5 \mathrm{mg})$ and ammonium sulfate $(2.5 \mathrm{mg})$. All the ampoules temperatures were set and controlled at $28^{\circ} \mathrm{C}$, then the microcalorimetric data will record by a computer automatically, when the power-time curve returned to baseline, the experiment was finished.

\subsection{Urease Assay}

Urease activity was measured using colorimetric method [18]. $2.5 \mathrm{~g}$ soil sample were mixed with $0.5 \mathrm{~mL}$ of toluene for $15 \mathrm{~min}$, then added to $2.5 \mathrm{~mL}$ of $10 \%$ urea and $5 \mathrm{~mL}$ citrate buffer (pH 6.7) in incubator at $38^{\circ} \mathrm{C}$ for $24 \mathrm{~h}$. Then with $38^{\circ} \mathrm{C}$ distilled water diluted, filtered, then $4 \mathrm{~mL}$ of sodium phenate and $3 \mathrm{~mL}$ of sodium hypochlorite were added to $1 \mathrm{~mL}$ filtrate and diluted to $50 \mathrm{~mL}$ for $20 \mathrm{~min}$, finally, it was measured at wavelengths of $578 \mathrm{~nm}$ using spectrophotometer.

\subsection{Soil Organic Matter}

Soil organic matter was determined by a standard potassium dichromate digest method [19]. $0.2500 \mathrm{~g}$ soil sample mixed with $5 \mathrm{ml}$ of $0.8000 \mathrm{~mol} \mathrm{~L}^{-1} \mathrm{~K}_{2} \mathrm{Cr}_{2} \mathrm{O}_{7}$ and $5 \mathrm{ml}$ of concentrated $\mathrm{H}_{2} \mathrm{SO}_{4}$ at $190^{\circ} \mathrm{C}$ for $5 \mathrm{~min}$, followed by titration of the extracts with standardized $\mathrm{FeSO}_{4}$.

\subsection{Statistical Analyses}

Data and graphs are presented in the results was carried out using Microsoft Excel and Origin8.0. , Standard analysis of variance (AMOVA) procedures were used to calculate treatment means.

\section{RESULTS}

\subsection{Microcalorimetry}

Five stages (trough winter stage, reviving stage, jointing stage, blossoming stage, maturing stage) of winter wheat under five $\mathrm{N}$ fertilizer rate treatments on microbial activity were analyzed. As illustrated in (Fig. 1), the power-time curves of soil microbial growth were influenced obviously by $\mathrm{N}$ fertilizer rate.

In order to better interpretation of the power-time curves, we calculated some parameters from the curves (Table 1), such as $Q_{\mathrm{T}}$ : the total heat production; $P$ max: the maximum heat production; Tmax: the time in the maximum heat production; $t$ : the time course of metabolism. These are very important parameters for evaluation of microbial metabolism. $Q_{\mathrm{T}}$ released heat production of soil microorganisms from beginning to end, in blossoming stage N0, N1, $\mathrm{N} 3$ had the lowest values, while N2 and N4 had the lowest values in maturing stage. The values of $Q_{\mathrm{T}}$ had light difference at trough, reviving and jointing stages with increasing nitrogen fertilizer rate, but increasing nitrogen fertilizer rate that $Q_{\mathrm{T}}$ showed a trend of obvious $\mathrm{W}$ shape at blossoming stage and at maturing stage $Q_{\mathrm{T}}$ decreased with increasing nitrogen fertilizer rate. N3 had the highest $P \max$ which affected by the $\mathrm{N}$ fertilizer rate, with the $\mathrm{N}$ fertilizer rate increasing, Pmax showed increased firstly and then decreased trend in each stage, respectively. N3 all reach the highest thermal power in every stage. Tmax is the time when the soil microbial activity reached the maximum heat production. N0, N1, N2, N4 in jointing stage had the maximum time, and $\mathrm{N} 3$ had the maximum time in blossoming stage, N0, N1, N4 had the minimal time in blossoming stage, $\mathrm{N} 2$ in trough winter stage had the minimal time, N3 in reviving stage had the minimal time and each stage' $\mathrm{s}$ time had little change. $t$ which indicated the time of soil microorganisms metabolism in the whole process, in trough winter and reviving stage, no influence on $\mathrm{N}$ rate (Table 1), jointing stage had the longest time of $t$, blossoming stage used greater time of $t$ than maturing stage except for N0,N1.

\subsection{Soil Urease, Organic Matter in Different Growth Stages}

In the whole growth of winter wheat, soil urease activity in the jointing stage reached the peak, then it dropped to the low in maturing stage (Fig. 2). From sowing to trough winter stage, the change of urease activity depended on $\mathrm{N}$ rate, four $\mathrm{N}$ treatment increased $36.0 \%, 25.9 \%, 64.6 \%, 44.3 \%$ compared to $\mathrm{CK}$, respectively. In reviving stage, urease activity had a slight increase. However, urease activity picked up quickly in jointing stage and reached the top of 


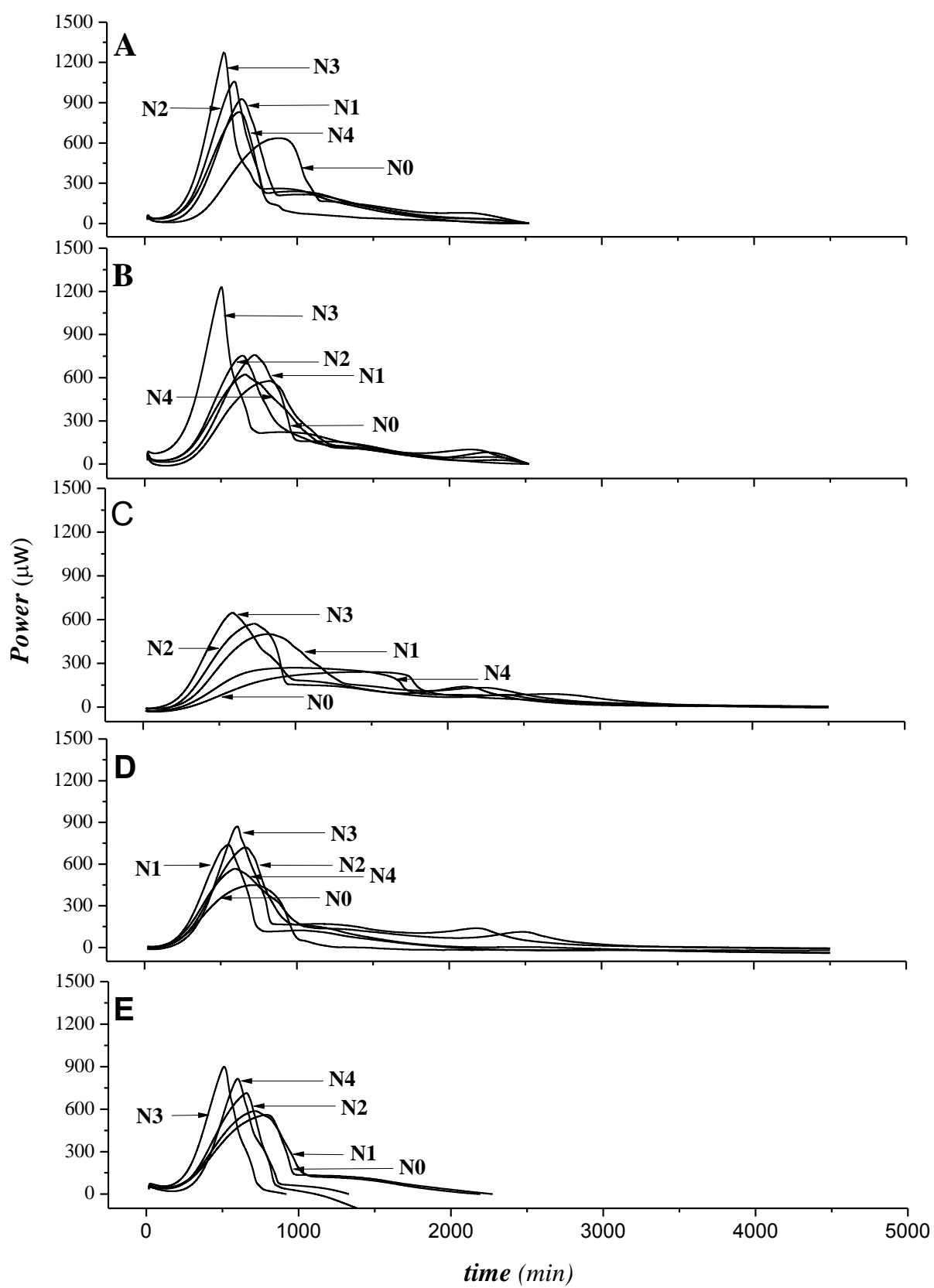

Fig. (1) Power-time of microorganism under different nitrogen fertilizer rate in the presence of rough winter stage (A), Reviving stage (B), Jointing stage $(\mathbf{C})$, Blossoming stage (D) and Maturing stage (E).

growth. After it started to fall in blossoming stage, a little improve in maturing stage. These results clearly indicate that urease activity in $\mathrm{N}$ treatment increased compared to $\mathrm{CK}$ and $\mathrm{N} 3$ treatment of urease activity was higher than other $\mathrm{N}$ treatment. Thus, the different of soil urease activity related to the amount of nitrogen rate.

Continuous farming without the addition of $\mathrm{N}$ fertilizer over 3 years caused decrease in the SOM. The different content of SOM were due to the $\mathrm{N}$ fertilizer, but had no significant differences across $\mathrm{N}$ treatments and litter variability occurring at five stages (Fig. 3). SOM of whole growth stage content ranged from 15.1 to $12.6 \mathrm{~g} \mathrm{~kg}^{-1}, 16.3$ to $15.2 \mathrm{~g} \mathrm{~kg}^{-1}, 16.6$ to $16.0 \mathrm{~g} \mathrm{~kg}^{-1}, 16.9$ to $16.6 \mathrm{~g} \mathrm{~kg}^{-1}, 17.0$ to
$14.9 \mathrm{~g} \mathrm{~kg}^{-1}$ in the $\mathrm{N} 0, \mathrm{~N} 1, \mathrm{~N} 2, \mathrm{~N} 3$ and N4 treatments. Five treatments from sowing to maturing stage the SOM decreased by $16.7 \%, 6.9 \%, 3.1 \%, 2.0 \%, 12.2 \%$, respectively. SOM were lower by the maturing stage and N3 treatment had the lowest variation.

\subsection{The Relationship between Soil Urease and Organic Matter}

Variance analysis (Table 2) showed that the effect of $\mathrm{N}$ fertilizer rate and growth stage on urease and organic matter is different. The effect of $\mathrm{N}$ fertilizer rate and growth stage on urease was greater than organic matter. For urease, the 
Table 1. Thermokinetic parameters for microbial growth at $28^{\circ} \mathrm{C}$ under different nitrogen fertilizer at different stage.

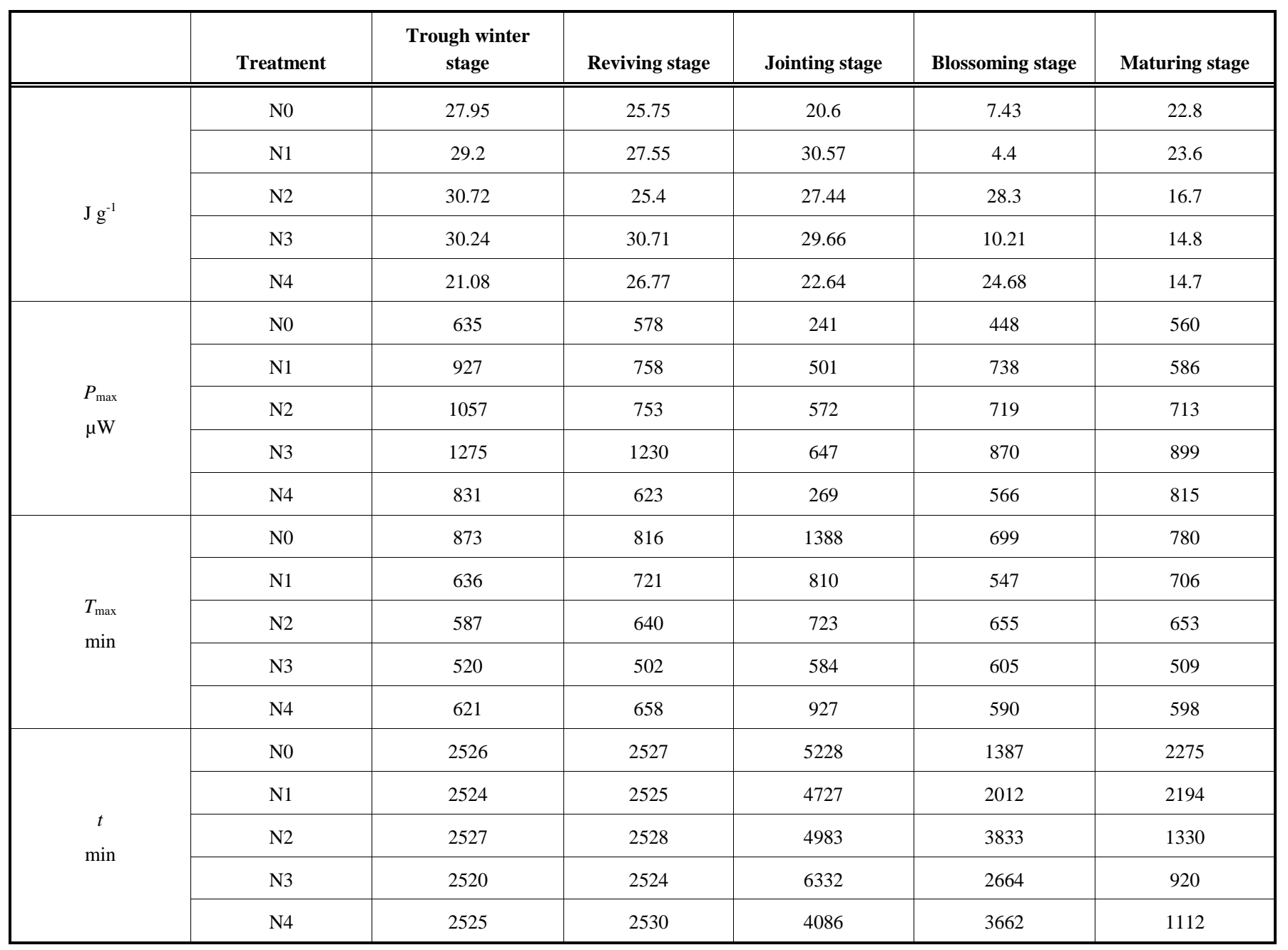

Table 2. Effect of nitrogen fertilizer rate and growth stage on soil urease and organic matter.

\begin{tabular}{|c|c|c|}
\hline Item & Urease & Organic Matter \\
\hline \hline N fertilizer rate & 25.32 & 10.72 \\
\hline Growth stage & 61.24 & 5.37 \\
\hline
\end{tabular}

effect of growth stage was stronger than $\mathrm{N}$ fertilizer rate, for organic matter, $\mathrm{N}$ fertilizer rate is more influence on growth stage.

\section{DISCUSSION}

\subsection{Effect of Nitrogen Rate on Soil Microbial Activity}

Soil microbial activity is influenced by many factors (fertilizer, field management, soil physicochemical properties and so on) and microorganisms are important to most soil processes which depend on nutrient, carbon and energy of soil. From the result in the present study that change of microbial activity due to $\mathrm{N}$ fertilizer change and in different stage applied to soil (Fig. 1). This is in agreement [20]. N3 in five stages had the highest microbial activity, N0 of the power-time curves had the low activity compared to other $\mathrm{N}$ fertilizer treatments. In general, the rhizosphere microorganisms is sensitive to inorganic fertilizer, when crop root exudates contain a large number of $\mathrm{C} / \mathrm{N}$, would cause the rhizosphere of $\mathrm{N}$ in a deficiency environment. In this study, above or below N3' treatments all had lower microbial activity than N3 (Fig. 1). Because $\mathrm{N}$ fertilizer within a certain range that microbial quantity showed an increase with the increasing of $\mathrm{N}$ fertilizer rate, but excessiveness of $\mathrm{N}$ fertilizer was disadvantageous to carbon source, and the increasing of $\mathrm{N}$ fertilizer rate increased the growth of crop and water consumption, decreased soil water content and the number of microorganism.

In this paper, $\mathrm{N}$ fertilizer staging added to the consumption of $\mathrm{N}$ of soil, promoted the soil microbial breeding, thus improved the soil enzyme activity and soil 


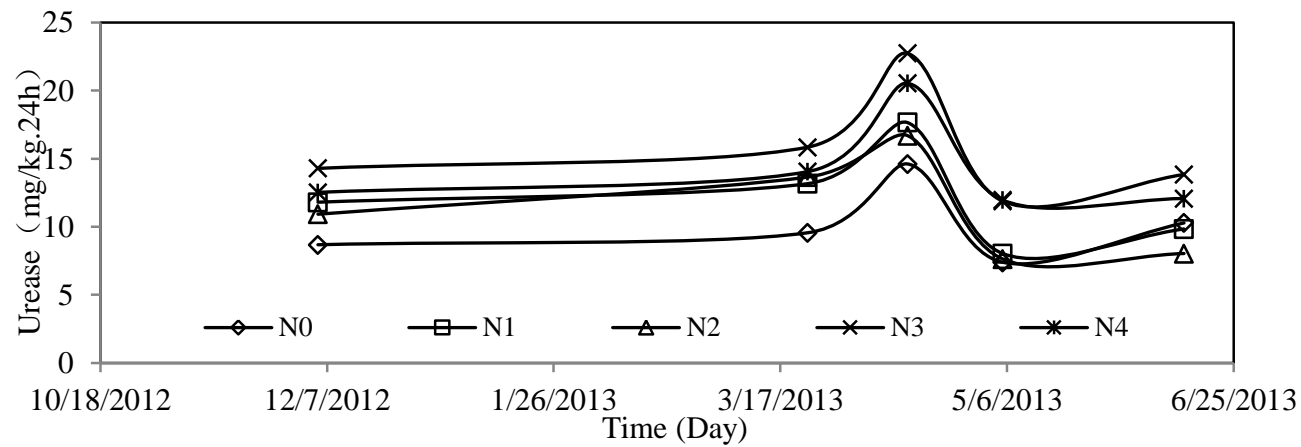

Fig. (2). The effect of nitrogen fertilizer on the urease at rough winter stage, reviving stage, jointing stage, blossoming stage and maturing stage.

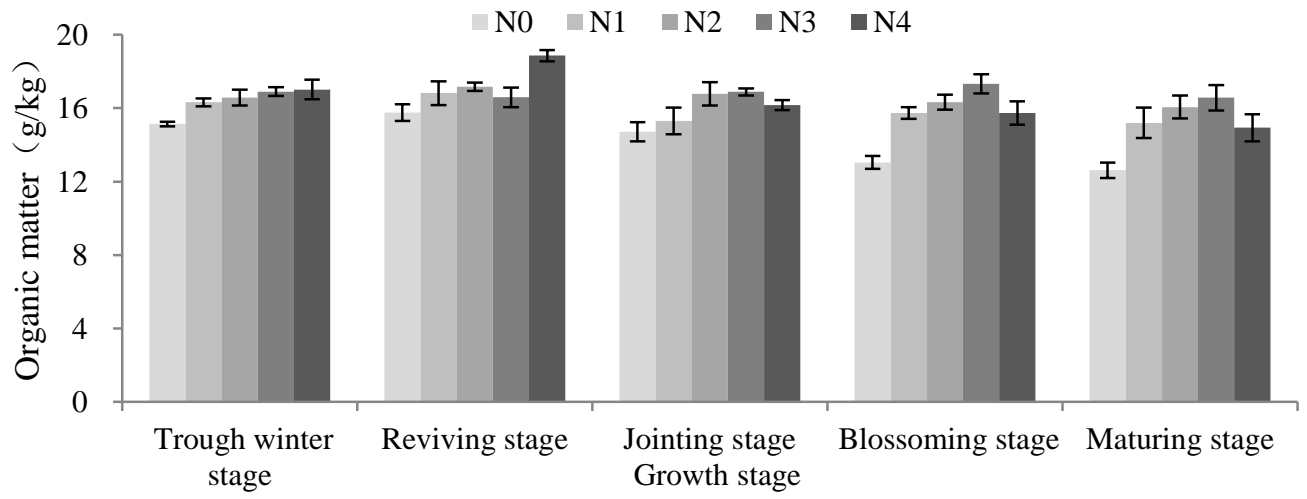

Fig. (3). Effect of nitrogen fertilizer on organic matter at different stage.

fertility. In the case of low $\mathrm{N}$ fertilizer, low nutrition stress increase wheat root exudates, strengthen the soil nutrition and balance of nutrition metabolism of biological, promoted the soil microbial community, quantity and activity.

\subsection{Effect of Nitrogen Rate on Soil Urease and Organic Matter}

Organic management increases overall enzyme activity $[21,22]$. During the whole winter wheat growing season, from sowing stage to reviving stage is the vegetative growth phase of winter wheat which had less dry matter accumulation and $\mathrm{N}$ fertilizer rate, at this point urease activity slight low, so it need to reduce the $\mathrm{N}$ fertilizer rate [23]. From jointing to blossoming stage, with the dry matter accumulation increased, the demand for $\mathrm{N}$ fertilizer increased, and in jointing stage, the root activity and root weight density of winter wheat enhanced [24], root exudates is the important source of soil enzyme [25], result in urease activity rapidly increased in jointing stage and reached the peak of the whole growing season, therefore, increased the $\mathrm{N}$ fertilizer rate is necessary. In this study, urease activity in trough winter stage was higher than the mid-to late stage due to the irrigation, meanwhile, in the mid-to late stage soil permeability variation for irrigation and urease activity decreased. Urea applied into the soil by the urea enzyme hydrolysis into ammonia then absorbed by the winter wheat. Because ammonia is easily to volatilize and under the condition of high temperature and enough water that complete the conversion process in a short time. Than it would result in winter wheat can not absorb ammonia and $\mathrm{N}$ fertilizer loss. Besides, $\mathrm{N}$ fertilizer can inhibit urease production. Therefore, a long term and high concentration of $\mathrm{N}$ fertilizer cause agricultural system that the effective nutrient mineralization and cycle ability reduced, leading to the decrease of available nitrogen.

The present dates demonstrate that under the addition of different $\mathrm{N}$ fertilizer rate over 3 years was slightly changed SOM content. [26] reported that fertilizer can improve crop growth, yield and organic inputs into soil, but a little positive impact on SOM [27]. The present study showed that SOM quality was improved by addition of proper $\mathrm{N}$ fertilizer. In trough winter stage, SOM content of five treatments had little difference. But N4 had the highest value of SOM in the reviving stage due to the high $\mathrm{N}$ fertilizer rate. To jointing stage, N4 of SOM decreased and similar trend continued to maturing stage, the same to N1. Moreover, N2 and N3 both had very little change in whole stages, this means that proper fertilizer is conducive to the preservation of SOM.

\subsection{Nitrogen Fertilizer Management is Very Important in Agriculture System}

Fertilizer plays an important role in agricultural system. M.J. Hawkesford reported that crop wanted high yield need nitrogen [28] which for storage proteins in the grain and photosynthesis, efficient and proper management of nitrogen not only was significant for sustainability of agricultural system, but also it can avoid adverse environmental impacts of pollution. Higher than recommended rate of $\mathrm{N}$ fertilizer would reduce microbial biomass C [29]. In this study, after applying $\mathrm{N}$ fertilizer to soil, the relationship with soil activity in the growth season dynamic changes and soil nutrient status. Under different $\mathrm{N}$ treatments the microbial activity 
was higher than control observed (Fig. 1). N1, N2 and N4 had lower microbial activity than N3.

According to [30,31], the quantity and quality of $\mathrm{N}$ and carbon (C) and SOM inputs are the overriding controls on soil microbial activity. Soil microorganisms play an important role in increasing soil fertility, improving soil structure and promoting the material circulation in nature. Some heterotrophic microorganisms can decompose animal and plant residues and organic fertilizer, then re-synthetic form humus. When soil temperature is low, poor ventilation, anaerobic microbial activity increased, humus synthetic speed is accelerated, and accumulated of humus, humus was influence on soil fertility. Under the condition of high temperature, adequate soil moisture, good ventilation, aerobic microbial activity increased, humus decomposition, releasing nutrients for plant uptake. Azotobacter fixed nitrogen in the air, as their protein, when these bacteria death and decomposition, the nitrogen can be absorbed by the plant and accumulated nitrogen in soil. Nitrifying bacteria decomposed organic fertilizer into ammonia then converted to effective nitrate for the plant. Some of fungi can decompose cellulose, lignin and pectin and so on. The accumulation of fungal hyphae can make the physical structure of the soil improvement. Actinomyces can produce antibiotics.

\section{CONCLUSION}

The present study showed that high soil microbial activity due to $\mathrm{N}$ fertilizer rate, while soil organic matter was not affected obviously, in contrast, soil urease activity had a difference in each stage and at the jointing stage reached the peak. The variance analysis results indicated $\mathrm{N}$ fertilizer rate and growth stage both can influence the soil urease activity and soil organic matter. It is concluded that proper $\mathrm{N}$ fertilizer rate is important for optimal microbial growth while topdressing $\mathrm{N}$ fertilizer at jointing stage it is beneficial to the soil urease activity.

\section{CONFLICT OF INTEREST}

The authors confirm that this article content has no conflict of interest.

\section{ACKNOWLEDGEMENTS}

This work is supported in part by grants from the International Joint Key Project from Chinese Ministry of Science and Technology (2010DFB23160), National Natural Science Foundation of China (41273092), Public welfare project of Chinese Ministry of Environmental Protection (201409042), and Overseas, Hong Kong and Macau Young Scholars Collaborative Research Fund (41328005).

\section{REFERENCES}

[1] Shen JL, Tang AH, Liu XJ, Fangmeier A, Goulding KT, Zhang FS. High concentrations and dry deposition of reactive nitrogen species at two sites in the North China Plain. Environ Pollut 2009; 157: 3106-13.

[2] Basso B, Cammarano D, Fiorentino C, Ritchie JT. Wheat yield response to spatially variable nitrogen fertilizer in Mediterranean environment. Eur J Agron 2013; 51: 65-70.
[3] Li W, Li L, Sun J, et al. Effects of intercropping and nitrogen application on nitrate present in the profile of an Orthic Anthrosol in Northwest China. Agric Ecosyst Environ 2005; 105: 483-91.

[4] Chen D, Suter H, Islam A, Edis R, Freney JR, Walker CN. Prospects of improving efficiency of fertiliser nitrogen in Australian agriculture: a review of enhanced efficiency fertilisers. Aus J Soil Res 2008; 46: 289-301.

[5] Lu C, Fan L. Winter wheat yield potentials and yield gaps in the North China Plain. Field Crops Res 2013; 143: 98-105.

[6] Costanza R, d'Arge R, Groot RD, et al. The value of the world's ecosystem services and natural capital. Nature 1997; 387: 253-60.

[7] Akhtar A, Hisamuddin, Robab MI, Abbasi, Sharf R. Plant growth promoting Rhizobacteria An overview. J Nat Prod Plant Resour 2012; 2: 19-31.

[8] Singh JS, Pandey VC, Singh DP. Efficient soil microorganisms: A new dimension for sustainable agriculture and environmental development. Agric Ecosyst Environ 2011; 140(3-4): 339-53.

[9] de Vries FT, Hoffland E, van Eekeren N, Brussaard L, Bloem J. Fungal/bacterial ratios in grasslands with contrasting nitrogen management. Soil Biol Biochem 2006; 38(8): 2092-103.

[10] Tejada M, Dobao MM, Benitez C, Gonzalez JL. Study of composting of cotton residues. Bioresour Technol 2001; 79: 199202.

[11] Ryals R, Kaiser M, Torn MS, Berhe AA, Silver WL. Impacts of organic matter amendments on carbon and nitrogen dynamics in grassland soils. Soil Biol Biochem 2014; 68: 52-61.

[12] Lucchini P, Quilliam RS, De Luca TH, Vamerali T, Jones DL. Does biochar application alter heavy metal dynamics in agricultural soil? Agric Ecosyst Environ 2014; 184: 149-57.

[13] Kerek M, Drijber RA, Gaussoin RE. Labile soil organic matter as a potential nitrogen source in golf greens. Soil Biol Biochem 2003; 35(12): 1643-9.

[14] Di Bene C, Tavarini S, Mazzoncini M, Angelini LG. Changes in soil chemical parameters and organic matter balance after 13 years of ramie [Boehmeria nivea (L.) Gaud.] cultivation in the Mediterranean region. Eur J Agron 2011; 35(3): 154-63.

[15] Li M, Zhou X, Zhang Q, Cheng X. Consequences of afforestation for soil nitrogen dynamics in central China. Agric Ecosyst Environ 2014; 183: 40-6.

[16] Pandey D, Agrawal M, Bohra JS. Effects of conventional tillage and no tillage permutations on extracellular soil enzyme activities and microbial biomass under rice cultivation. Soil Tillage Res 2014; 136: 51-60.

[17] Liang Q, Chen H, Gong Y, Yang H, Fan M, Kuzyakov Y. Effects of 15 years of manure and mineral fertilizers on enzyme activities in particle-size fractions in a North China Plain soil. Eur J Soil Biol 2014; 60: 112-9.

[18] Guo H, Yao J, Cai M, et al. Effects of petroleum contamination on soil microbial numbers, metabolic activity and urease activity. Chemosphere 2012; 87(11): 1273-80.

[19] Walkley A, Black IA. An examination of degtjareff method for determining soil organic matter and a proposed modification of the chromic acid titration method. Soil Sci 1934; 37(1): 29-39.

[20] Geisseler D, Scow KM. Long-term effects of mineral fertilizers on soil microorganisms - A review. Soil Biol Biochem 2014; 75: 5463.

[21] Maeder P, Fliessbach A, Dubois D, Gunst L, Fried P, Niggli U. Soil fertility and biodiversity in organic farming. science 2002; 296: 1694-7.

[22] B Moeskops, Sukristiyonubowo, D. Buchan, et al. Soil microbial communities and activities under intensive organic and conventional vegetable farming in West Java, Indonesia. Appl Soil Ecol 2010; 45: 112-20.

[23] Dordas C. Dry matter, nitrogen and phosphorus accumulation, partitioning and remobilization as affected by $\mathrm{N}$ and $\mathrm{P}$ fertilization and source-sink relations. Eur J Agron 2009; 30: 129-39.

[24] Shi Z, Jing Q, Cai J, Jiang D, Cao W, Dai T. The fates of $15 \mathrm{~N}$ fertilizer in relation to root distributions of winter wheat under different N splits. Eur J Agron 2012; 40: 86-93.

[25] Kotroczó Z, Veres Z, Fekete I, et al. Soil enzyme activity in response to long-term organic matter manipulation. Soil Biol Biochem 2014; 70: 237-43.

[26] Hai L, Li XG, Li FM, Suo DR, Guggenberger G. Long-term fertilization and manuring effects on physically-separated soil organic matter pools under a wheat-wheat-maize cropping system in an arid region of China. Soil Biol Biochem 2010; 42: 253-9. 
[27] Lal R. Carbon sequestration in dryland ecosystems. Environ Manage 2004; 33: 528-44.

[28] Hawkesford MJ. Reducing the reliance on nitrogen fertilizer for wheat production. J Cereal Sci 2014; 59: 276-83.

[29] Lupwayi NZ, Lafond GP, Ziadi N, Grant CA. Soil microbial response to nitrogen fertilizer and tillage in barley and corn. Soil Tillage Res 2012; 118: 139-46.
[30] Kallenbach C, Grandy AS. Controls over soil microbial biomass responses to carbon amendments in agricultural systems: A metaanalysis. Agric Ecosyst Environ 2011; 144, pp. 241-52.

[31] Grandy AS, Strickland MS, Lauber CL, Bradford MA, Fierer N. The influence of microbial communities, management, and soil texture on soil organic matter chemistry. Geoderma 2009; 150: $278-86$.

(C) Jingjing et al.; Licensee Bentham Open.

This is an open access article licensed under the terms of the Creative Commons Attribution Non-Commercial License (http://creativecommons.org/licenses/ by-nc/3.0/) which permits unrestricted, non-commercial use, distribution and reproduction in any medium, provided the work is properly cited. 